\section{Testing for Fecal Calprotectin in Food Protein-Induced Enterocolitis Syndrome}

Khan S

Department of Allergy and Immunology, Apollo Gleneagles Hospital, Kolkata, India

J Investig Allergol Clin Immunol 2018; Vol. 28(4): 287-288 doi: 10.18176/jiaci.0249

Key words: Fecal calprotectin. FPIES; Non-IgE-mediated food allergies. Cow's milk protein allergy.

Palabras clave: Calprotectina fecal. FPIES. Alergias alimentarias no mediadas por lgE. Alergia a proteínas de leche de vaca.

Dear Editor:

I read with interest the medical update by Vila Sexto [1] on food protein-induced enterocolitis syndrome (FPIES) and would like to add my thoughts on the importance of noninvasive tests such as fecal calprotectin (FC) in this condition. Several fecal biomarkers (eg, $\beta$-defensin, TNF- $\alpha$, and eosinophil cationic protein) have been assessed in nonIgE-mediated gastrointestinal disorders, although FC appears to be the most reproducible and reliable [2]. It is important to emphasize that no single test can replace the information provided by the patient's symptoms and clinical assessment. Nevertheless, the availability of any biomarker would assist in diagnosis and counseling of patients and parents.

Calprotectin is a cytosolic $\mathrm{Ca}^{2}+/ \mathrm{Zn}$-binding protein present in neutrophils and monocytes that has antimicrobial action (by depriving microorganisms of zinc), immunomodulatory action, and antiprofilerative action [3]. Increased FC levels suggest gut mucosal inflammation that is easily confirmed by endoscopy and histology in inflammatory bowel disease. At the cellular level, increased FC has been associated with increased neutrophil migration towards the intestinal lumen. Just as nonIgE-dependent mechanisms account for the inflammation seen in inflammatory bowel disease, a similar parallel is drawn for FPIES, wherein skin tests and levels of specific IgE against food proteins (eg, cow's milk protein [CMP], egg, wheat, and soy) are negative. Therefore, gut proteins such as $\beta$-defensin, eosinophil cationic protein, TNF- $\alpha$, and calprotectin in fecal samples can act as surrogate markers of cellular response. The Table lists studies showing that estimation of FC may prove to be a useful biomarker in FPIES $[2,4,5]$. Beşer et al [4] showed a higher FC level in non-IgE-mediated disease before elimination of CMP that decreased after elimination of CMP, although levels were still higher than in IgE-mediated disease. Merras-Salmio et al [2] showed that the Mann-Whitney test $P$ values were significantly different between geometric means of FC values in IgE-mediated vs non-IgE-mediated disease during elimination of CMP [2].

The exact cut-off limits of FC in FPIES remain to be determined, although these will undoubtedly be dependent on age, duration of the elimination diet, and intercurrent gastrointestinal infections. Further studies are required to determine whether FC is useful in non-IgE-mediated food allergies, since gastrointestinal involvement is more common here than in IgE-mediated disease.

\section{References}

1. Vila Sexto L. Latest Insights on Food Protein-Induced Enterocolitis Syndrome: An Emerging Medical Condition. J Investig Allergol Clin Immunol. 2018;28:13-23.

2. Merras-Salmio L, Kolho KL, Pelkonen AS, Kuitunen M, Mäkelä MJ, Savilahti E. Markers of gut mucosal inflammation and cow's milk specific immunoglobulins in non-IgE cow's milk allergy. Clin Transl Allergy. 2014;4:8.

3. Sipponen T, Kolho KL. Fecal calprotectin in diagnosis and clinical assessment of inflammatory bowel disease. Scand J Gastroenterol. 2015;50:74-80.

4. Beşer OF, Sancak S, Erkan T, Kutlu T, Cokuğraş H, Cokuğraş FÇ. Can Fecal Calprotectin Level Be Used as a Markers of Inflammation in the Diagnosis and Follow-Up of Cow's Milk Protein Allergy? Allergy Asthma Immunol Res. 2014;6:33-8.

5. Trillo Belizón C, Ortega Páez E, Medina Claros AF, Rodríguez Sánchez I, Reina González A, Vera Medialdea R et al. Faecal calprotectin as an aid to the diagnosis of non-lgE mediated cow's milk protein allergy. An Pediatr (Barc). 2016;84:318-23. 
Table. Studies on Fecal Calprotectin in IgE- and Non-IgE Mediated Gastrointestinal Diseases

\begin{tabular}{|c|c|c|c|c|c|}
\hline $\begin{array}{l}\text { Study } \\
\text { Location, y }\end{array}$ & $\begin{array}{c}\text { Number of Children } \\
\text { (Age Range) }\end{array}$ & \multicolumn{3}{|c|}{ Fecal Calprotectin Levels and Clinical Groups } & Reference \\
\hline \multirow[t]{9}{*}{ Turkey, 2014} & \multirow{9}{*}{$\begin{array}{c}19 \text { healthy } \\
\text { children aged } \\
1 \text { to } 31 \text { mo } \\
32 \text { CMPA patients } \\
\text { (24 IgE-mediated, } \\
8 \text { non-IgE-mediated) }\end{array}$} & \multicolumn{3}{|c|}{ Mean FC value was 296 (94) $\mu \mathrm{g} / \mathrm{g}$ (healthy children) } & [4] \\
\hline & & \multicolumn{3}{|c|}{ Pre-CMP elimination diet mean FC value } & \\
\hline & & Non-IgE group $(n=8)$ & \multicolumn{2}{|l|}{$886(278) \mu \mathrm{g} / \mathrm{g}$} & \\
\hline & & Control group $(n=19)$ & \multicolumn{2}{|l|}{$296(94) \mu \mathrm{g} / \mathrm{g}$} & \\
\hline & & \multicolumn{3}{|l|}{$P<.001$} & \\
\hline & & & $\begin{array}{l}\text { Pre-CMP } \\
\text { elimination, } \\
\text { Mean FC value }\end{array}$ & $\begin{array}{l}\text { Post-CMP } \\
\text { elimination diet, } \\
\text { Mean FC value }\end{array}$ & \\
\hline & & $\begin{array}{l}\text { IgE-mediated group } \\
(\mathrm{n}=24)\end{array}$ & $392(209) \mu \mathrm{g} / \mathrm{g}$ & $218(90) \mu \mathrm{g} / \mathrm{g}$ & \\
\hline & & $\begin{array}{l}\text { Non-IgE-mediated } \\
\text { group }(n=8)\end{array}$ & $886(278) \mu \mathrm{g} / \mathrm{g}$ & $359(288) \mu \mathrm{g} / \mathrm{g}$ & \\
\hline & & & $P=.001$ & $P=.025$ & \\
\hline
\end{tabular}

Finland, 201457 young children aged $0-4$ y
Percentage change in geometric mean of FC, IgA and $\beta$-defensin 2 levels

\begin{tabular}{|l|l|l|l|}
\hline $\begin{array}{l}\text { \% change following } \\
\text { introduction of CMP }\end{array}$ & $\mathrm{FC}$ & $\operatorname{IgA}$ & $\beta$-defensin 2 \\
\hline $\begin{array}{l}\text { IgE-mediated group } \\
(\mathrm{n}=18)\end{array}$ & $15 \%$ & $-11 \%$ & $23 \%$ \\
\hline $\begin{array}{l}\text { Non-IgE-mediated } \\
\text { group }(\mathrm{n}=39)\end{array}$ & $18 \%$ & $-2.2 \%$ & $39 \%$ \\
\hline
\end{tabular}

Fecal $\beta$-defensin 2 and IgA showed high levels of within-group variation but the differences between the groups were insignificant.

$\begin{array}{ccl}\text { Spain, } 2016 & \begin{array}{c}82 \text { infants } \\ \text { aged } 1-12 \text { mo }\end{array} & \begin{array}{l}\text { Statistically significant relationship of high FC levels between infants } \\ \text { with non-IgE-mediated CMPA and controls; FC }<138 \mu \mathrm{g} / \mathrm{g} \text { excludes FPIES }\end{array}\end{array}$

Abbreviations: CMP, cow's milk protein; CMPA, cow's milk protein allergy; FC, fecal calprotectin; FPIES, food protein-induced enterocolitis syndrome.
Manuscript received February 22, 2018; accepted for publication February 27, 2018.

\section{Sujoy Khan}

Department of Allergy and Immunology

Apollo Gleneagles Hospital

58, Canal Circular Road

Kolkata - 700 054, West Bengal

India

E-mail: sujoykhan@gmail.com 